\title{
Gene profiling of $\mathrm{CD} 11 \mathrm{~b}^{+}$and $\mathrm{CD} 11 \mathrm{~b}^{-} \mathrm{B} 1$ cell subsets reveals potential cell sorting artifacts
}

To the Editor:

In a recent issue of The Journal of Experimental Medicine, Griffin and Rothstein described two subsets within the human B1 cell compartment: a major CD11b subset (9/10th of the population) and a minor CD $11 b^{+}$subset $(1 / 10$ th of the population), with the latter being increased in lupus (Griffin and Rothstein, 2011).

Griffin and Rothstein (2011) analyzed these two B1 cell subsets using gene profiling and compared these gene profiles with those of naive and memory blood B cells. A heat map is shown in Fig. 2 of their paper. This figure highlights a distinct expression profile for each of the CD11b and CD11b subsets compared with naive and memory B cells.

Using the data deposited in the National Center for Biotechnology Information GEO database (GSE29717), we performed the same comparison and found that the gene profile of each of these subsets argues in favor of a different conclusion.

For CD11b ${ }^{-}$B1 cells, the 50 most discriminating genes (comparing this subset to $\mathrm{CD} 11 \mathrm{~b}^{+} \mathrm{B} 1$ cells, naive cells, and memory $\mathrm{B}$ cells) include those encoding $\mathrm{CD} 8 \alpha$; $\mathrm{CD} 3 \zeta$; CD3 $\delta$; CD2; CD5; CD7; CD96; LAT; MAL; granzymes A, B, H, and $\mathrm{K}$; and granulolysin (Fig. 1 A). This profile resembles that of cytotoxic $\mathrm{CD}^{+} \mathrm{T}$ cells. This subset also expresses CD19, CD22, and other B cell markers, which does not discriminate them from naive and memory $\mathrm{B}$ cells. Thus CD11b $\mathrm{b}^{-}$B1 cells most likely consist of $\mathrm{CD}^{+} \mathrm{T}$ cell-B cell doublets.

For $\mathrm{CD} 11 \mathrm{~b}^{+} \mathrm{B} 1$ cells, overexpressed genes include those encoding $\operatorname{SIRP} \alpha$, CD33, CD68, CD163, CD302, IL-1 APRIL (TNFSF13), and CD14 (Fig. 1 B). These genes correspond to a myeloid profile. Underexpressed genes include those encoding CD79A and CD79B, and other $\mathrm{B}$ cell markers, including TACI, BAFF-R (TNFRSF13b and TNFRSF13c), BLK, CD19, and CD27
A

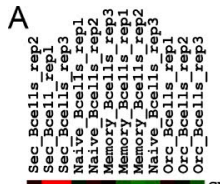

B

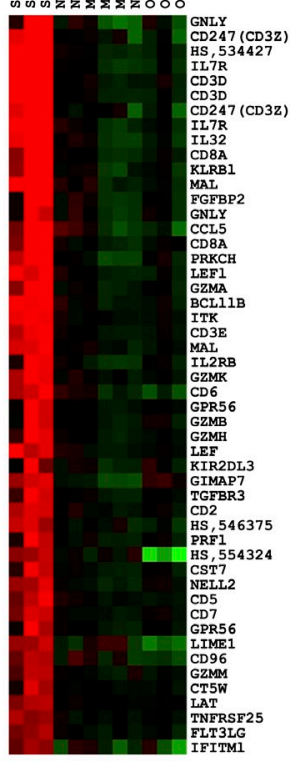

Sec_B cells: CD11b $b^{-}$cells
Orc_B cells: CD $11 b^{+} B$ cells
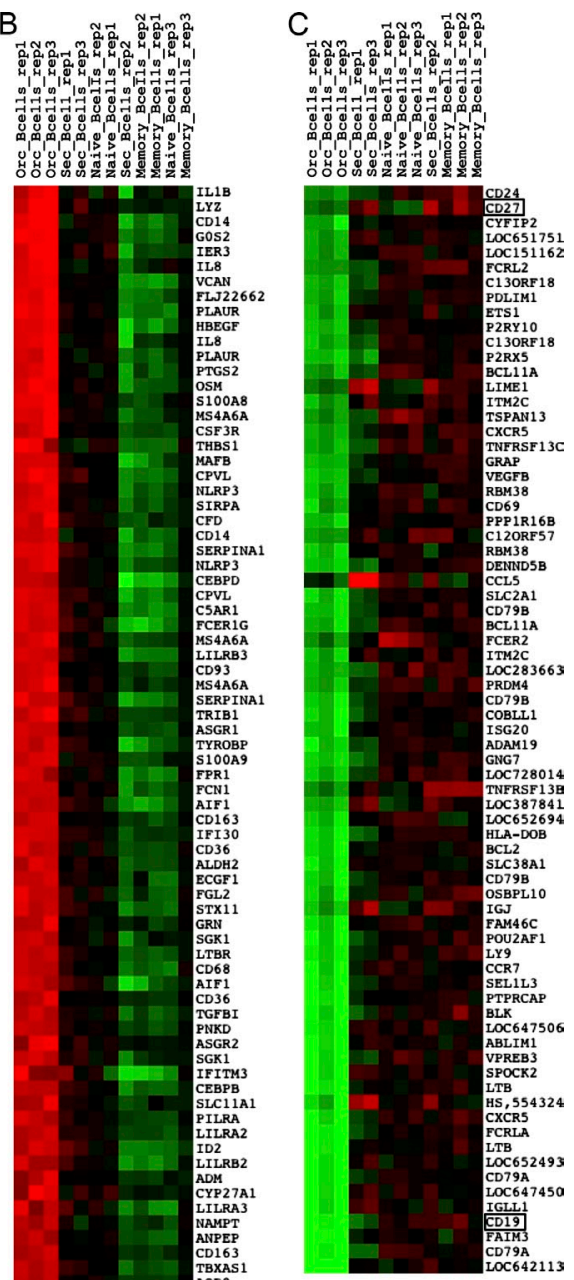

Figure 1. Gene expression profiles of human $C D 11 b^{+}$and $C D 11 b^{-} B 1$ cell subsets. (A) Top 50 overexpressed genes discriminating CD11 $b^{-} B 1$ cells from CD11 $b^{+}$, naïve, and memory B cells. Sec_B cells, CD11b $b^{-}$B1 cells. Orc_B cells, CD11b+ B1 cells. (B) Top 106 overexpressed genes discriminating CD11 b B1 cells from CD11 $b^{-}$, naïve, and memory B cells. (C) Top 73 underexpressed genes discriminating CD $11 b^{+}$ B1 cells from $C D 11 b^{-}$, naive, and memory B cells. The total number of genes displayed, which represent an unbiased list of genes according to their ranking order in the comparison, was selected to include most of the discriminating genes selected by Griffin and Rothstein in the heat map in Fig. 2 of their paper. A classical red/green heat map display is used for overexpressed/under-expressed genes. 
(Fig. 1 C). The latter two markers were among the criteria used by Griffin and Rothstein to isolate these cells. This subset thus represents cells of the monocyte lineage that were sorted by unspecific (possibly Fc-mediated) staining as CD $19^{+} \mathrm{CD} 27^{+}$cells. The CD11b and CD14 phenotype is thus not surprising.

There probably exists a human B cell subset with a spontaneous capacity to secrete $\operatorname{IgM}$, as reported in the two papers by Griffin and colleagues on human B1 cells (Griffin and Rothstein, 2011; Griffin et al., 2011). However, the characteristics described by these authors thus far pertain to cells that appear to represent two different types of cell sorting artifacts.

We thank Nicolas Cagnard (Bioinformatics platform, Paris Descartes) for performing the microarray analysis.

Claude-Agnès Reynaud and Jean-Claude Weill

Institut National de la Santé et de la Recherche Médicale Unité 783 "Développement du système immunitaire", Université Paris Descartes, Faculté de Médecine - Site Necker-Enfants Malades, Paris, France
CORRESPONDENCE

Claude-Agnes Reynaud (claude-agnes.reynaud@ inserm.fr) OR Jean-Claude Weill (jean-claude.weill@ inserm.fr)

\section{REFERENCES}

Griffin, D.O., and T.L. Rothstein. 2011 A small CD11b(+) human B1 cell subpopulation stimulates $\mathrm{T}$ cells and is expanded in lupus. J. Exp. Med. 208:2591-2598. http:// dx.doi.org/10.1084/jem.20110978

Griffin, D.O., N.E. Holodick, and T.L. Rothstein. 2011 Human B1 cells in umbilical cord and adult peripheral blood express the novel phenotype CD20+ CD27+ CD43+ CD70J. Exp. Med. 208:67-80. http://dx.doi.org/10 $.1084 / \mathrm{jem} .20101499$

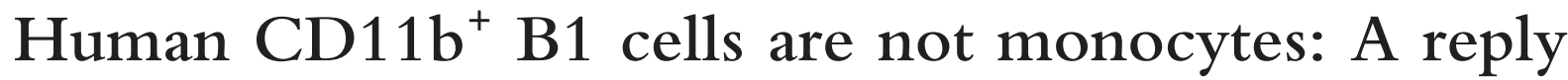 to "Gene profiling of CD11b' and CD11b' B1 cell subsets reveals potential cell sorting artifacts"}

\section{Griffin et al., respond:}

In January 2011, we reported the unique $\mathrm{CD} 20^{+} \mathrm{CD} 27^{+} \mathrm{CD} 43^{+}$phenotype of human B1 cells (Griffin et al., 2011a). In December 2011, we reported that the human B1 cell pool consists of functionally distinct $\mathrm{CD} 11 \mathrm{~b}^{-}$and $\mathrm{CD} 11 \mathrm{~b}^{+}$ populations, with the former particularly proficient at antibody secretion and the latter particularly efficient in stimulating $T$ cells (Griffin and Rothstein, 2011). We also noted that the frequency of $\mathrm{CD} 11 \mathrm{~b}^{+} \mathrm{B} 1$ cells is increased in the circulation of patients with lupus. As part of this work, we included microarray data that pointed to transcriptional differences between CD11b ${ }^{-}$and CD $11 b^{+}$ $\mathrm{B} 1$ cells. We have read with great interest the letter by Reynaud and Weill, who have mined the microarray data we deposited in the National Center for Biotechnology Information (NCBI) repository and drawn inferences, incorrectly as it turns out, regarding the nature and origin of CD11 ${ }^{-}$and CD $11 b^{+}$ B1 cells.

Reynaud and Weill speculated that $\mathrm{CD}_{11 \mathrm{~b}}{ }^{-} \mathrm{B} 1$ cells represent B cell-T cell doublets because this population, in aggregate, expressed genes characteristic of $\mathrm{T}$ cells along with genes characteristic of B cells. The potential issue of B cell$\mathrm{T}$ cell doublets, raised previously by these same authors (Descatoire et al., 2011), is a topic we have already addressed by demonstrating that our sort-purified B1 cells exist as singlets (Griffin and Rothstein, 2011; Griffin et al., 2011b). At the same time, we identified procedures that can be used to circumvent the potential problem of doublet events (Griffin et al., 2011b). In our published work, we reported that B1 cells sortpurified without $\mathrm{CD}^{-}$gating contained an estimated $1-3 \% \mathrm{CD}^{+}$events (Griffin and Rothstein, 2011; Griffin et al., 2011b). We have now sort-purified $\mathrm{CD}_{11 b^{-}}$B1 cells again, exactly as was done to generate our published microarray results, and have analyzed three independent postsort samples for CD3 expression, along with purified $\mathrm{T}$ cells (Fig. 1 A). We again find a very small proportion of $\mathrm{CD}^{+}$events $(1.9 \pm 0.66 \%$; mean \pm SEM) in the CD11b ${ }^{-}$B1 cell population. This very low level of CD3 positivity is likely attributable to a minor degree of $\mathrm{T}$ cell contamination that could account for the appearance of very low levels of some characteristically
$\mathrm{T}$ cell transcripts among CD11bB1 cells. In keeping with this, flow cytometric analysis of unsorted CD19enriched PBMCs demonstrates a small degree of CD2, CD7, CD8, and CD3 staining among $\mathrm{CD} 11 \mathrm{~b}^{-} \mathrm{B} 1$ cells that is eliminated by CD3 exclusion and subsequent analysis of $\mathrm{CD}^{-} \mathrm{CD} 20^{+} \mathrm{CD} 27^{+}$ $\mathrm{CD} 43^{+} \mathrm{CD}_{11 \mathrm{~b}}{ }^{-} \mathrm{B} 1$ cells (Fig. 1, B and $\mathrm{C})$. Importantly, when CD3 exclusion is combined with sort purification, expression of T cell genes such as CD7, CD8, and granzyme A is essentially eliminated (to $<0.2 \%$ that of $\mathrm{CD}^{+} \mathrm{CD} 20^{-}$ $\mathrm{T}$ cells from the same samples), as assessed by TaqMan QPCR (unpublished data). Collectively, these results indicate that $\mathrm{CD} 11 \mathrm{~b}^{-} \mathrm{B} 1$ cells represent a distinct $\mathrm{B}$ cell population, as we previously reported. They are not doublets and do not express multiple $\mathrm{T}$ cell markers. Our deposited NCBI data show minor amplification of some characteristically $\mathrm{T}$ cell genes caused by the presence of very few $\mathrm{T}$ cells in the samples used for microarray analysis.

Reynaud and Weill also contend that CD11b ${ }^{+}$B1 cells are not B cells, but are monocytes, because this population underexpressed some characteristically 

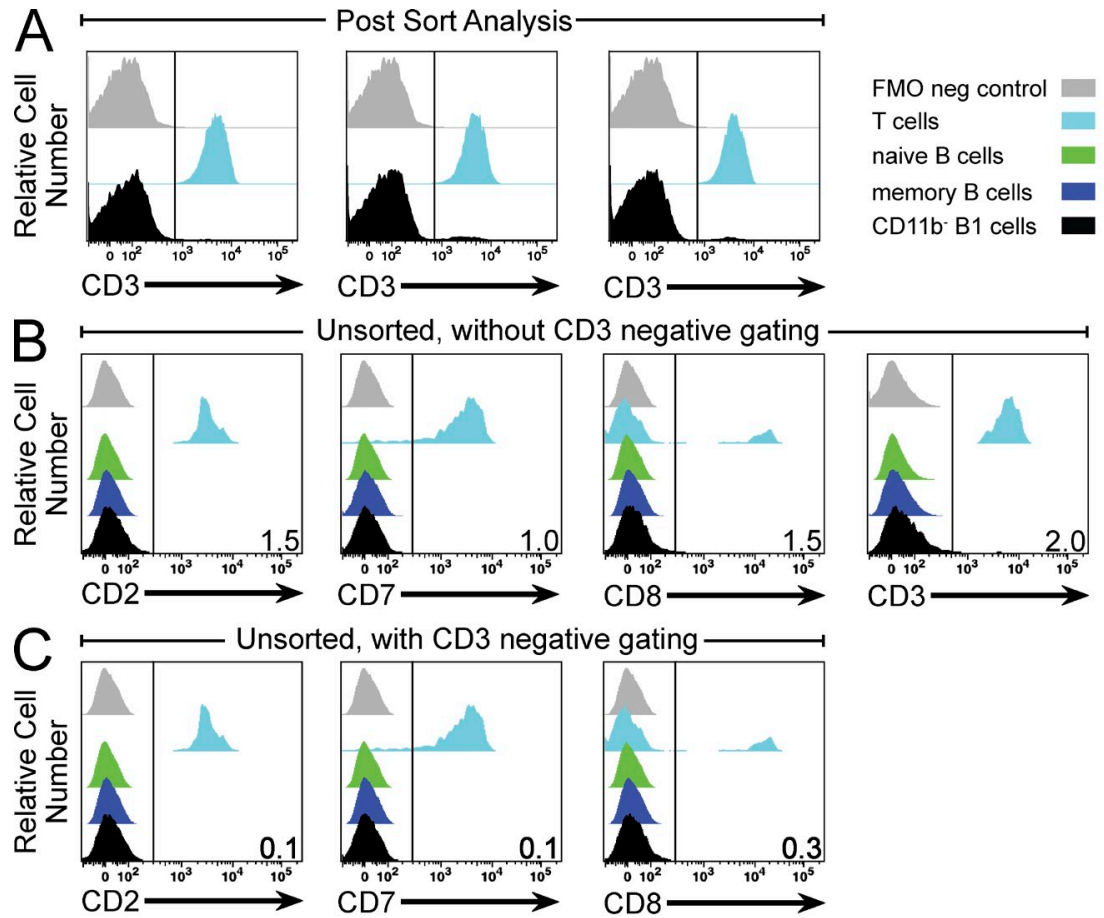
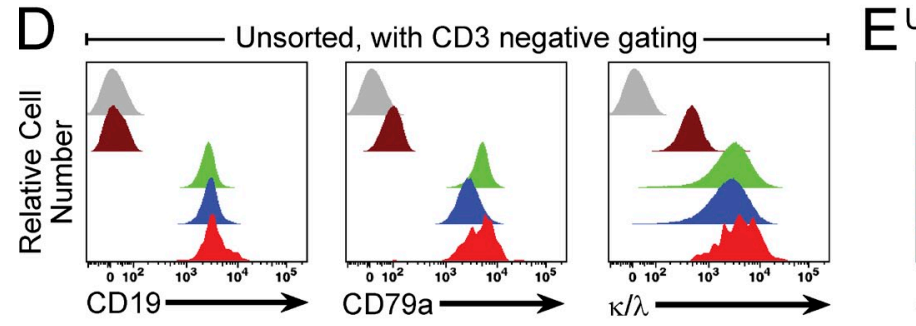

Unsorted, with CD3
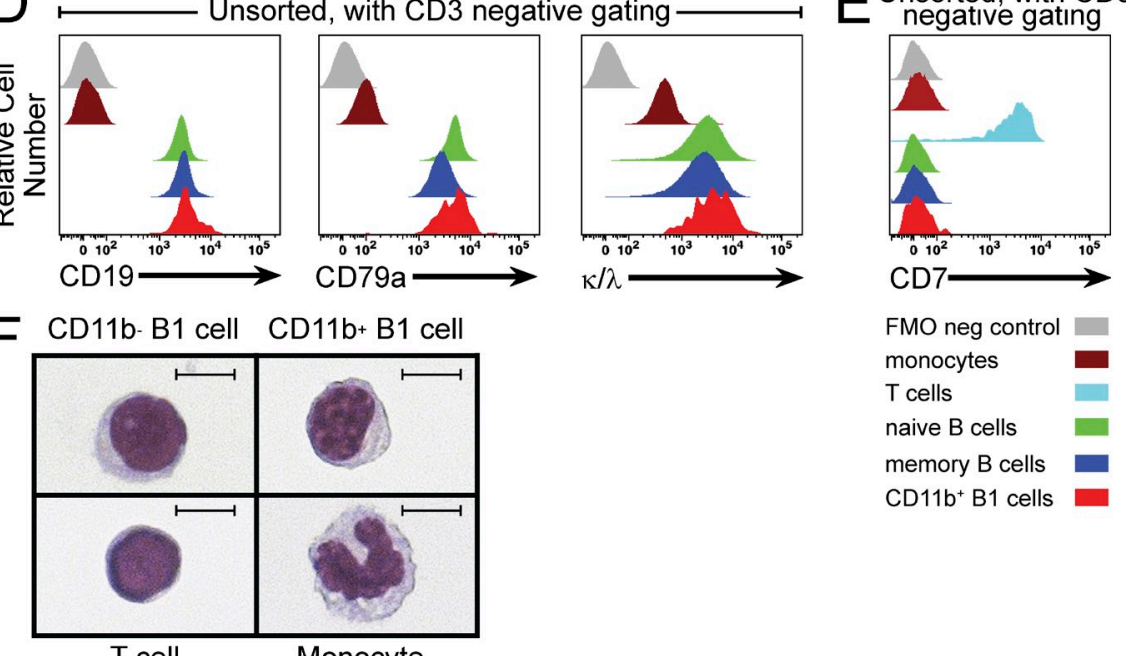

T cell

Monocyte

Figure 1. $C D 11 b^{-}$and $C D 11 b^{+} B 1$ cells are $B$ cells, not T cells or monocytes. (A) Adult PBMCs from three separate donors were CD19 enriched and immunofluorescently stained for CD116, CD20, CD27, and CD43.

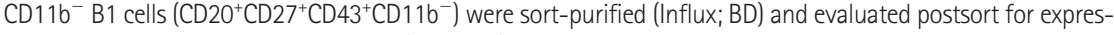
sion of $C D 3$ by flow cytometric analysis (LSRII; BD), and then compared with separately purified T cells, as indicated. (B and C) Adult PBMCs were CD19-enriched and immunofluorescently stained for CD11b, CD20, CD27, and $\mathrm{CD} 43$, as well as $\mathrm{CD} 2, \mathrm{CD} 3, \mathrm{CD} 7$, and $\mathrm{CD} 8$. The expression of $\mathrm{T}$ cell markers on naive $\left(\mathrm{CD} 2 \mathrm{O}^{+} \mathrm{CD} 27^{-} \mathrm{CD} 43^{-}\right)$, memory $\left(\mathrm{CD} 2 \mathrm{O}^{+} \mathrm{CD} 27^{+} \mathrm{CD} 43^{-}\right)$, and $\mathrm{CD} 11 \mathrm{~b}^{-} \mathrm{B} 1\left(\mathrm{CD} 2 \mathrm{O}^{+} \mathrm{CD} 27^{+} \mathrm{CD} 43^{+} \mathrm{CD} 11 \mathrm{~b}^{-}\right)$cells was evaluated by flow cytometric analysis and compared with T cells $\left(\mathrm{CD}^{+} \mathrm{CD}^{-} \mathrm{O}^{-}\right.$), as indicated (B). $\mathrm{B}$ cells were gated to exclude $\mathrm{CD}^{+}$events, and the expression of $\mathrm{T}$ cells markers was evaluated on $\mathrm{CD} 11 b^{-} \mathrm{B} 1$ cells by flow cytometric analysis and compared with $\mathrm{T}$ cells $\left(\mathrm{CD} 3^{+} \mathrm{CD} 2 \mathrm{O}^{-}\right.$), as indicated (C). (D) Adult PBMCs were immunofluorescently stained for $\mathrm{CD} 11 \mathrm{~b}, \mathrm{CD} 20$, CD27, and CD43, as well as CD19, CD79a, and $\kappa$ and $\lambda$ light chains (combined). $B$ cells were gated to exclude $\mathrm{CD}^{+}$events, and naive, memory, and $\mathrm{CD} 11 \mathrm{~b}^{+} \mathrm{B} 1$ cells were then evaluated for expression of $\mathrm{B}$ cell markers by flow cytometric analysis and compared with $\mathrm{T}$ cells $\left(\mathrm{CD}^{+} \mathrm{CD} 2 \mathrm{O}^{-}\right)$and monocytes $\left(\mathrm{CD} 11 \mathrm{~b}^{+} \mathrm{CD} 3^{-} \mathrm{CD} 2 \mathrm{O}^{-}\right)$, as indicated. (E) Adult PBMCs were CD19 enriched and immunofluorescently stained for CD116, CD20, CD27, and CD43, as well as CD7. B cells were gated to exclude $C D 3^{+}$events, and naive, memory, and $C D 11 b^{+} B 1$ cells were then evaluated for CD7 expression by flow cytometric analysis and compared with T cells and monocytes, as indicated. (F) Sort-purified CD11b $b^{-}$1 cells, CD11 b B1 cells, T cells, and monocytes were cytocentrifuged onto glass slides, stained with Wright-Giemsa, and examined by light microscopy. Representative images for each cell type are shown. Bars, $5 \mu \mathrm{m}$. Results shown in B-F represent one of three separate donors.
B cell genes and overexpressed some characteristically monocyte genes by microarray. Although some B cell genes were not well expressed by CD11 $\mathrm{b}^{+} \mathrm{B} 1$ cells, the corresponding proteins are expressed normally, as shown by immunofluorescent staining. For example, CD19 and CD79a (Fig. 1 D), as well as CD21, CD22, and BAFFR (not depicted), are expressed on $\mathrm{CD}_{11 \mathrm{~b}^{+}} \mathrm{B} 1$ cells at levels similar to those on naive and memory B cells. These staining results do not represent nonspecific binding, as $\mathrm{CD}_{11 \mathrm{~b}^{+}} \mathrm{B} 1$ cells are negative for staining with $\mathrm{CD} 7$ (Fig. $1 \mathrm{E}$ ), CD2, CD3, and CD8 (not depicted), as well as CD80 and CD71 (Griffin and Rothstein, 2011). Importantly, CD11b ${ }^{+}$B1 cells all express surface immunoglobulin, as demonstrated by positive staining with anti- $\kappa$ and anti- $\lambda$ Ig light chain antibodies conjugated to the same fluorophore (Fig. 1 D). Consistent with this, additional evidence that $\mathrm{CD} 11 \mathrm{~b}^{+} \mathrm{B} 1$ cells belong to the $\mathrm{B}$ cell lineage is provided by single-cell PCR amplification of rearranged immunoglobulin (Tiller et al., 2008; Griffin et al., 2011a), which we find to be even more efficient in $\mathrm{CD}_{11 \mathrm{~b}^{+}} \mathrm{B} 1$ cells than naive B cells from the same samples (unpublished data). On the basis of immunoglobulin gene rearrangement, B cell receptor expression, and expression of characteristically B-cell surface antigens, CD11 $\mathrm{b}^{+}$ B1 cells are B cells.

The notion that $\mathrm{CD}_{11 \mathrm{~b}^{+}} \mathrm{B} 1$ cells express monocyte genes is entirely consistent with what is known about mouse B1 cells. Expression of monocyte genes by some human B1 cells fits well with an extensive literature indicating a close relationship between B1 cells and monocytes, extending even to B1 cell phagocytic activity (Cumano et al., 1992; Borrello and Phipps, 1996; Almeida et al., 2001; Montecino-Rodriguez et al., 2001; Ghosn et al., 2006; Kawamoto, 2006; Popi et al., 2009; Parra et al., 2011). This does not mean, however, that CD $11 b^{+}$B1 cells are monocytes, as can be readily seen by the morphology of $\mathrm{CD} 11 \mathrm{~b}^{+} \mathrm{B} 1$ cells, which is quite different from the distinctive features of monocytes (Fig. 1 F). 
In sum, the mining of our microarray data by Reynaud and Weill has led them to speculative inferences that are firmly contradicted by an extensive body of evidence. Our work has established the overall phenotype of human B1 cells, as well as the nature and characteristics of two functionally distinct human B1 cell subpopulations, one of which is increased in frequency in the blood of lupus patients.

Daniel O. Griffin, ${ }^{1,2}$ Tam Quach, $^{2}$

Franak Batliwalla, ${ }^{2}$ Dennis Andreopoulos, ${ }^{2}$

Nichol E. Holodick, ${ }^{2}$ and Thomas L. Rothstein ${ }^{2,3,4}$

'Elmezzi Graduate School of Molecular Medicine and ${ }^{2}$ Center and for Oncology and Cell Biology, the Feinstein Institute for Medical Research, Manhasset, NY 11030

${ }^{3}$ Department of Medicine and ${ }^{4}$ Department of Molecular Medicine, Hofstra North Shore-LIJ School of Medicine, Manhasset, NY 11030

\section{CORRESPONDENCE}

Thomas L. Rothstein: tr@nshs.edu

\section{REFERENCES}

Almeida, S.R., L.S. Aroeira, E. Frymuller, M.A. Dias, C.S. Bogsan, J.D. Lopes, and M. Mariano. 2001. Mouse B-1 cell-derived mononuclear phagocyte, a novel cellular component of acute non-specific inflammatory exudate.
Int. Immunol. 13:1193-1201. http://dx.doi .org/10.1093/intimm/13.9.1193

Borrello, M.A., and R.P. Phipps. 1996. The B/macrophage cell: an elusive link between CD5+ B lymphocytes and macrophages. Immunol. Today. 17:471-475. http://dx.doi .org/10.1016/0167-5699(96)20031-B

Cumano, A., C.J. Paige, N.N. Iscove, and G. Brady. 1992. Bipotential precursors of $\mathrm{B}$ cells and macrophages in murine fetal liver. Nature. 356:612-615. http://dx.doi .org/10.1038/356612a0

Descatoire, M., J.C. Weill, C.A. Reynaud, and S. Weller. 2011. A human equivalent of mouse B-1 cells? J. Exp. Med. 208:2563-2564. http://dx.doi.org/10.1084/jem.20112232

Ghosn, E.E., M. Russo, and S.R. Almeida. 2006. Nitric oxide-dependent killing of Cryptococcus neoformans by B-1-derived mononuclear phagocyte. J. Leukoc. Biol. 80:36-44. http:// dx.doi.org/10.1189/jlb.1005603

Griffin, D.O., and T.L. Rothstein. 2011. A small $\mathrm{CD} 11 \mathrm{~b}(+)$ human B1 cell subpopulation stimulates $\mathrm{T}$ cells and is expanded in lupus. J. Exp. Med. 208:2591-2598. http://dx.doi .org/10.1084/jem.20110978

Griffin, D.O., N.E. Holodick, and T.L. Rothstein. 2011a. Human B1 cells in umbilical cord and adult peripheral blood express the novel phenotype $\mathrm{CD} 20^{+} \mathrm{CD} 27^{+} \mathrm{CD} 43^{+} \mathrm{CD} 70^{-}$. J. Exp. Med. 208:67-80. http://dx.doi .org/10.1084/jem.20101499

Griffin, D.O., N.E. Holodick, and T.L. Rothstein. 2011b. Human B1 cells are CD3-: A reply to "A human equivalent of mouse B-1 cells?" and "The nature of circulating CD27+CD43+
B cells."J. Exp. Med. 208:2566-2569. http:// dx.doi.org/10.1084/jem.20111761

Kawamoto, H. 2006. A close developmental relationship between the lymphoid and myeloid lineages. Trends Immunol. 27:169-175. http://dx.doi.org/10.1016/j.it.2006.02.004

Montecino-Rodriguez, E., H. Leathers, and $\mathrm{K}$. Dorshkind. 2001. Bipotential B-macrophage progenitors are present in adult bone marrow. Nat. Immunol. 2:83-88. http://dx.doi .org/10.1038/83210

Parra, D., A.M. Rieger, J. Li, Y.A. Zhang, L.M Randall, C.A. Hunter, D.R. Barreda, and J.O. Sunyer. 2011. Pivotal advance: peritoneal cavity B-1 B cells have phagocytic and microbicidal capacities and present phagocytosed antigen to CD4+ T cells. J. Leukoc. Biol. http://dx.doi.org/10.1189/jlb.0711372.

Popi,A.F., F.L. Motta, R.A. Mortara, S. Schenkman, J.D. Lopes, and M. Mariano. 2009. Co-ordinated expression of lymphoid and myeloid specific transcription factors during B-1b cell differentiation into mononuclear phagocytes in vitro. Immunology. 126:114-122. http://dx.doi .org/10.1111/j.1365-2567.2008.02883.x

Reynaud, C.-A., and J.-C. Weill. 2012. Gene profiling of $\mathrm{CD}_{11 b^{+}}$and $\mathrm{CD}_{11} \mathrm{~b}^{-} \mathrm{B} 1$ cell subsets reveals potential cell sorting artifacts. J. Exp. Med. 209:433-436.

Tiller, T., E. Meffre, S. Yurasov, M. Tsuiji, M.C. Nussenzweig, and H. Wardemann. 2008. Efficient generation of monoclonal antibodies from single human B cells by single cell RT-PCR and expression vector cloning. J. Immunol. Methods. 329:112-124. http:// dx.doi.org/10.1016/j.jim.2007.09.017 